\title{
CARA MENGUASAI ENGLISH CONVERSATION DENGAN CEPAT PADA ATLET KARATE BATAM
}

\author{
Mhd. Johan \\ Universitas Putera Batam (UPB), Batam, Indonesia \\ e-mail: thorshid@gmail.com \\ Winda Evyanto \\ Universitas Putera Batam (UPB), Batam, Indonesia \\ e-mail: winda731016@gmail.com \\ Gaguk Rudianto \\ Universitas Putera Batam (UPB), Batam, Indonesia \\ e-mail: gagukrudianto@gmail.com
}

\begin{abstract}
English is one of the world's official languages. All information is published in English and all progress and events can be known through English. Therefore, it is only natural that the sports world is also obliged to know English. Athletes will find it difficult to adapt if they don't master English. An athlete who is able to speak English so the development of his knowledge will progress more quickly. In Batam, there are a lot of kohai-kohai who don't speak English, so we tried to share a little of our knowledges to invite them how they can master English better and easily. To master English, an athlete needs language proficiency. Therefore we emphasized on our kohai-kohai so that they get used to using English in their daily life. Here we also emphasized on my kohai-kohai that they must be able to distinguish words, because in English words can affect meaning. Besides that, we also emphasized on the kohai-kohai how to pronounce the words, this is very important in mastering English. After that, how to apply those words in a sentence. The procedure for making sentences is no less important than the above. Sentences can also determine the meaning or topic to be conveyed to the interlocutors.
\end{abstract}

Keywords: kohai, English Conversation

\section{PENDAHULUAN}

Bahasa merupakan alat komunikasi yang digunakan oleh setiap orang untuk berkomunikasi (Field, 2003.). Hal ini bertujuan untuk menyampaikan sesuatu baik formal maupun informal hal itu juga disampaikan oleh Bonvillain. (Bonvillain, 1977) mengatakan bahwa bahasa merupakan bagian integral dari sikap manusia yang melakukan komunikasi antar sesamanya. Bahasa Inggris adalah bahasa Internasional, bahasa Inggris menjadi salah satu bahasa favorit di Indonesia, sehingga bahasa Inggris termasuk salah mata pelajaran di sekolah-sekolah di negara kita ini. Untuk mengasai bahasa Inggris kita membutuhkan waktu yang lama. Hal tersebut dapat kita rasakan pada saat mengikuti ujian bahasa Inggris di sekolah. Sehingga bahasa Inggris menjadi salah satu mata pelajaran yang ditakuti di sekolah. Hal ini terbukti, ketika anak-anak mendapatkan nilai di bawah rata-rata. Disamping 
itu (Nadra, 2010) mengatakan bahwa dalam kehidupan sehari-hari kita tak teterlepas dari penggunaan bahasa, baik bahasa lisan maupun bahasa tulis.

Bahasa dan komunikasi tidak dapat dipisahkan dari para penutur. Sebagaimana yang disampaikan oleh (Semi, 2008) bahasa dan komunikasi merupakan suatu hasil kreasi estetik dan bahasa itu adalah fakta sosial yang bukan merupakan benda tertutup yang mengabdi pada struktur formalnya sendiri sendiri, melainkan merupakan gejala relasional. Menurut pandangan penulis bahasa itu harus dibangun sejak manusia dilahirkan sehingga estetik dalam berbahasa tidak terlupakan sebagaimana yang dikatakan oleh (-McCarthy., 2002) mengatakan seseorang mulai menggunakan bahasa sejak dia dilahirkan. Hal ini dapat dikatakan proses manusia mendapatkan bahasa. Di samping itu (Johan, Evyanto, 2021) mengatakan proses bahasa tidak bisa dilepaskan dari penguasaan vocabulary.

Karena hal tersebut di atas, maka dari itu kami mencoba membantu para kohai-kohai untuk menguasai bahasa Inggris. Menurut kami karateka-karateka muda harus pandai bahasa Inggris, sekira mereka tidak bisa bahasa Inggris maka mereka akan mengalami masalah dalam pertandingan internasional serta menguasai materi yang berbahasa Inggris. Selanjutnya mereka juga mengalami kesulitan memahami instruksi pelatih asing. Serta mereka juga mengalami masalah informsasi teknologi karate. Kemudian mereka sering bertanding keluar negeri, pada saat mereka bertanding keluar negeri mereka membutuhkan komunikasi antar sesama karateka sedunia. Bahasa yang mereka gunakan dalam komunikasi tersebut tentu bahasa Inggris.

Pemerintah telah mengagendakan mata pelajaran sudah dijadikan sebagai mata pelajaran wajib di sekolah. Agenda ini sudah lama dimulai akan tetapi muridmurid itu belum sanggup mengaplikasikan bahasa Inggris itu dalam kehidupan sehari-hari. Dengan adanya masalah seperti ini, hal ini telah menyita perhatian para guru-guru bahasa Inggris di setiap sekolah. Sebenarnya apa yang kurang pada kita, apa program pemerintah salah atau teknik pengajarannya. Untuk mencermati hal itu kita tidak perlu saling menyalahkan satu sama lainnya. Mari kita evaluasi semuanya kembali, baik program, cara pengajaran, maupun hal lain yang dirasa perlu untuk diperbaiki.

Sebagaimana kita ketahui negara tetangga kita sudah mampu mengaplikasikan bahasa Inggris dalam kehidupan mereka setiap harinya. Bagaimana dengan kita, kalau boleh kita mengingat kembali, dulunya mereka belajar sama kita, sekarang mereka jauh meninggalkan kita dalam penggunaan bahasa Inggris sehari-harinya. Memang sungguh ironis sekali rasanya kalau kita tidak mampu mengajari anak-anak kita berkomunikasi dengan menggunakan bahasa Inggris setiap harinya.

Sekarang negara kita banyak tertinggal dari negera-negara asean ataupun asia. Negera-negara tetangga kita itu dapat mengaplikasikan bahasa Inggris setiap harinya. Sementara kita malas menggunakan bahasa Inggris. Untuk menguasai bahasa Inggris banyak hal positif yang kita dapatkan, rata-rata ilmu yang ditulis pada buku-buku menggunkan bahasa Inggris. Begitu juga komunikasi diantara masyarakat ASEAN ataupun ASIA mereka telah mengaplikasikannya secara merata. Di samping menguasai bahasa Inggris mereka tidak meninggalkan bahasa 
nasional mereka. Johan \& Wijayanti, (2020) dengan menguasai Bahasa kita dapat bergaul lebih luas baik dengan masyarakat sekitar maupun dengan orang asing.

Dengan munculnya masalah-masalah di atas, membuat pengabdi ingin mengajak semua kohai-kohai saya untuk bicara bahasa Inggris setiap harinya sebab menurut pengamatan pengabdi, mereka sangat membutuhkannya apabila mengikuti turnamen tingkat Internasional. Tidak hanya sebatas itu, materi ini dapat menunjang prestasi mereka di sekolah (bagi yang masih sekolah) sedangkan bagi yang bekerja dapat menambah wawasan dan keahlian dalam berbahasa. Kemudian bagi karateka yang sedang mencari pekerjaan dapat memperdalam kemampuan mereka dalam berbahasa. Mengamati permasalahan tersebut dapat disimpulkan bahwa: Bagaimana tips bicara bahasa Inggris dengan cepat? Bagaimana memperbaiki tips bicara dengan benar?

\section{METODE}

Waktu dan Tempat Pelaksanaan, peserta pembinaan ini adalah semua kohaikohai dojo Inkanas Lembaga Adat Melayu kota Batam. Peralatan yang digunakan dalam kegiatan pengabdian ini akan dijelaskan pada tabel.

Tabel 1. Peralatan Kegiatan Pengabdian

\begin{tabular}{|l|l|c|c|}
\hline No & Peralatan & Jumlah & Sumber \\
\hline 1 & aula /dojo & 1 ruang & LAM \\
\hline 2 & foto copy & 30 lembar & - \\
\hline 3 & pena & 30 atang & - \\
\hline
\end{tabular}

Metode pelaksanaan Kegiatan pengabdian kepada masyarakat ini dilakukan hanya sekali pertemuan yang melibatkan semua kohai berjumlah 25 peserta. Adapun jadwal kegiatan dapat dilihat pada tabel berikut:

Tabel 2. Susunan Acara Pertemuan Pertama (Pembukaan)

\begin{tabular}{|l|l|l|l|}
\hline No & Waktu & Kegiatan & Pengisi Kegiatan \\
\hline 1 & $10-12-2017$ & Tradisi karate & Asisten pelatih dojo \\
& 07.30 & & \\
\hline 2 & $10-12-2017$ & Taiso/pemanasan & Asisten pelatih \\
& 07.35 & Lari & Asisten pelatih \\
& $\begin{array}{l}10-12-2017 \\
08.00\end{array}$ & Acara Inti : pengabdian dan & $\begin{array}{l}\text { Mhd. Johan, Winda Evyanto, dan } \\
\text { Gaguk Rudianto }\end{array}$ \\
\hline 3 & \multicolumn{2}{|l|}{\begin{tabular}{l} 
Persiapan penyajian materi. \\
\hline
\end{tabular}}
\end{tabular}

Metode untuk menyelesaikan masalah yang ditawarkan oleh pengabdi berupa:

- Pengabdi memberikan pelatihan berbentuk praktek langsung. 
- $\quad$ Tim Pengabdi memastikan bahwa seluruh kohai paham dengan materi yang disampaikan, dan diberikan waktu untuk berdiskusi.

Evaluasi pelaksanaan kegiatan pada pengabdian pembinaan ini dapat dilihat pada capaian target yang telah diuraikan pada tabel 2 beberapa target yang akan dicapai pada pembinaan ini yaitu:

- Meningkatkan pemahaman terhadap kosa kata

- Meningkatkan kualitas dan kuantitas pemahaman terhadap vocabulary

- Adanya peningkatan pemahaman dan keterampilan kohai pada conversation

- Adanya peningkatan pada pemahaman pada ujaran

Keberlanjutan dari pengabdian ini mestilah ada, setiap dua kali dalam seminggu mereka tetap mengulang apa yang sudah mereka dapatkan. Perlu diingat kegiatan ini sifatnya melatih keahliah, untuk melatih keahlian itu dibutuhkan latihan yang rutin dan sekurang-kurangnya satu jam dalam sehari-hari mereka harus berkomunikasi.

\section{HASIL DAN PEMBAHASAN}

\subsection{Hasil}

Untuk menguasai bahasa Inggris banyak hal yang mesti dikuasai, di antaranya: mental, pronounciation, vocabulary, penguasaan struktur kata. Setelah hal yang sedehana di atas dikuasai berarti kohai telah memenuhi syarat untuk bicara menggunakan bahasa Inggris.

Di sini penulis sengaja mendahulukan mental karena kalau mental bicara tidak ada maka kohai tidak akan bisa bicara dengan menggunakan bahasa Inggris. Hal rasa bersalah akan menimbulkan rasa malu, sehingga kohai tidak dapat bicara menggunakan bahasa Inggris. Karena otak pembicara tadi tidak dapat mengolah kata yang akan disampaikan kepada lawan bicara mereka. Jadi untuk menguasai bahasa Inggris kohai harus mengalahkan rasa malu dalam menguasai bahasa Inggris. Hindarilah rasa rendah diri antar sesama, anggaplah lawan bicara kita itu sebagai partner. Untuk menghindari rasa malu dalam bicara sebaiknya, kohai latihan dulu sendiri, latihan itu dapat dilakukan di kamar, dengan melafalkan beberapa kalimat atau pertanyaan.

Menurut wawancara yang penulis lakukan pada saat pengabdian tersebut, penulis menjumpai rasa malu bicara pada para kohai-kohai tersebut, sebenarnya mereka sangat aktif dan bersemangat tetapi kalau dihadapkan dengan bahasa Inggris mereka banyak yang malu dalam menyampaikan pendapat. Sehingga penulis memberi tips pada mereka bagaimana bicara bahasa Inggris itu. Setelah penulis sampaikan tips tersebut, pikiran mereka jadi segar dan semangat mereka kembali muncul. Selain itu penulis juga mengatakan bahwa belajar bahasa inggris itu, kohai harus menguasai pronounciation. 

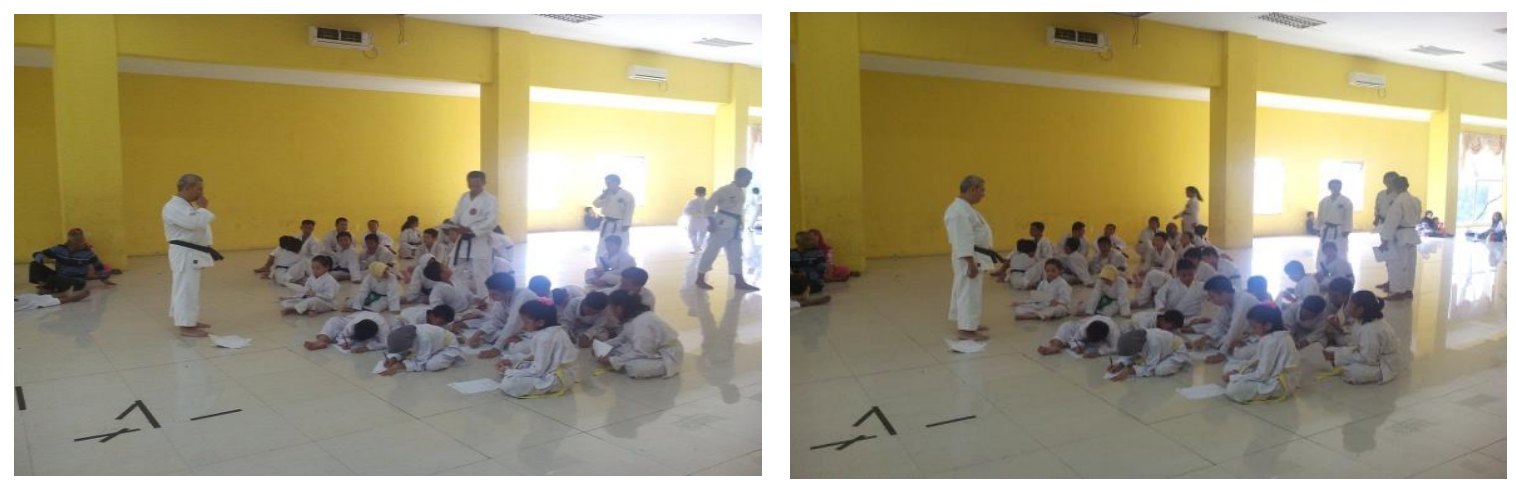

Gambar 1. Kegiatan pengabdian dengan peserta

Pronounciation adalah bagaimana cara menuturkan kata-kata dengan baik dan benar, kalau tuturannya sudah memenuhi standar, maka makna yang disampaikan kepada lawan bicara dapat dimengerti dengan baik. Penulis juga menyampaikan kepada kohai-kohai tersebut, bahwa pelafalan kata dalam bahasa Inggris sangat jauh berbeda dengan bahasa Indonesia.

Misalnya dalam melafalkan kata one yang berarti satu, dalam bahasa Inggris kata ini dilafalkan dengan $/ \mathrm{w} / \mathrm{n} /$. Bahasa Inggris memang berbeda dengan bahasa Indonesia, bahasa Inggris mempunyai cara baca yang berbeda dalam membaca fonemnya, seperti dalam membaca alphabet. Seperti:

Table 3. Cara pelafalan abjad Bahasa Inggris

\begin{tabular}{|c|c|c|c|c|c|}
\hline alpabet & Dibaca & alpabet & Dibaca & alpabet & dibaca \\
\hline A & /ei/ & $\mathrm{B}$ & /bi/ & $\mathrm{C}$ & $/ \mathrm{si} /$ \\
\hline D & /di/ & $E$ & /i/ & $\mathrm{F}$ & lef/ \\
\hline $\mathrm{G}$ & /ji/ & $\mathrm{H}$ & /eits/ & I & /ai/ \\
\hline $\mathrm{J}$ & /jei/ & $\mathrm{K}$ & /kei/ & L & /el/ \\
\hline$M$ & /em/ & $\mathrm{N}$ & /en/ & $\mathrm{O}$ & lou/ \\
\hline $\mathrm{P}$ & $/ \mathrm{pi} /$ & Q & /kiu/ & $\mathrm{R}$ & /ar, a;/ \\
\hline S & les/ & $\mathrm{T}$ & $/ \mathrm{ti} /$ & U & /yu/ \\
\hline $\mathrm{V}$ & $/ \mathrm{vi} /$ & W & /dabel yu/ & $X$ & leks/ \\
\hline $\bar{Y}$ & /wai/ & Z & /zi atau zet/ & & \\
\hline
\end{tabular}

Setelah menguasai pelafalan alpabet di atas, kohai juga harus melakukan pelafalan yang benar terhadap kata-kata yang akan dituturkan seperti:

/read/, dilafalkan /riad/ berarti membaca

/look/, dilafalkan /IU'/ berarti melihat

leat/, dilafalkan /iət/ berarti makan

/sit, dilafalkan /sit/ berarti duduk

/work/, /w3k/ berarti bekerja

/walk/, dilafalkan /wok/ berarti berjalan

/sleep/dilafalkan /sli:p/ berarti tidur, dan sebagainya 


\subsection{Pembahasan}

Dalam bicara bahasa Inggris, ada beberapa tips bagaimana seorang kohai dapat bicara dengan cepat dan benar. Setelah kohai memiliki kosa kata dan memahami cara pelafalan kata-kata dengan baik dan benar. Maka masuk ke tahap berikunya, kohai wajib mengaplikasikan kosa kata yang sudah dimiliki tadi ke dalam bentuk percakapan. Baik percakapan singkat maupun percakapan panjang. Tapi sebaiknya kohai harus mulai dengan percakapan yang pendek-pendek dan berhubungan dengan kegiatan sehari-hari. Di sisi lain kohai semestinya membiasakan menggunakan istilah-istilah bahasa Inggris yang bertujuan supaya kosa kata yang dikuasai tidak lupa. Di sisi lain kohai juga harus menguasai cara-cara bertanya dan harus menguasai jenis pertanyaan. Seperti menggunakan pertanyaan interrogative dan wh-question. Dalam percakapan hal seperti jadi penentu makna dan arah kemana percakapan tersebut.

Pertanyaan interrogative membutuhkan jawaban "ya atau tidak" sedangkan pertanyaan membutuhkan jawaban yang lebih lengkap dan jelas. Untuk membuat kedua pertanyaan itu, kita juga harus tahu struktur kata. Seperti: simple present atau past tense. Di samping itu kohai juga harus menguasai bentuk nominal dan verbal. Contoh kalimat nominal:

She is at home.

Dia (pr) berada di rumah.

My father is a doctor.

Ayah saya seorang dokter.

Ke dua kalimat di atas berbentuk nominal, maksudnya, kalimat tersebut tidak memiliki verb aktivitas, fungsi to be hanya sebagai penghubung antara subject dan object. Pada kalimat nominal, kadang-kadang to be mempunyai makna dan kadangkadang tidak bermakna. Seperti pada kalimat:

They are in the class room.

Mereka berada di dalam kelas.

Jadi to be di atas bermakna berada.

Sedangkan, kalimat

"she is sick"

Dia (pr) sakit

"she is beautiful"

Dia (pr) cantik

"I am late"

Saya terlambat, dan sebagainya.

Setelah kita perhatikan kalimat tersebut, to be pada kalimat itu tidak memiliki arti.

Dalam bicara kita perlu menyangkal suatu ujaran. Ujaran itu dapat disampaikan dalam kalimat negative. Adpun rumus kalimat itu dapat dilihat pada rumus di bawah ini.

Subject + to be (is, am, are) + not + Object (jika dalam simple present).

Subject + to be (was and were) + not+ Object (jika dalam past tense)

Contoh: 
(+) My house is in Batam

Rumah saya berada di Batam.

(-) my house is not in Batam

Rumah saya tidak di Batam.

(+) My parents are busy.

Orang tua saya sibuk.

(-) My parents are not busy

Orang tua saya tidak sibuk.

Rumus pertanyaan interrogative:

To be (is, am, are) + subject (pronoun) + Object (simple present)

atau

to be (was/were) + subject (pronoun) + object (past tense)

Pertanyaan interrogative adalah pertanyaan yang membutuhkan ketegasan, dengan menjawab yes atau no, pertanyaan itu seperti:

Are you sick?

Yes, I am.

No, I am not.

Apakah kamu sakit?

Is your father a doctor?

Yes, he is

No. He isn't.

Apakah ayahmu seorang dokter?

Are they students?

Yes, they are,

No. They aren't.

Apakah mereka pelajar?

Pertanyaan di atas adalah jenis pertanyaan interrogative dalam bentuk nominal. Di samping itu kohai juga harus menguasai bentuk verbal. Seperti rumus di bawah:

Do/does + subject + verb + Object

Contoh:

She studies English at school

Dia (pr) belajar bahasa Inggris di sekolah

Does she study English at school?

Yes, she does

No, she doesn't

Apakah dia (pr) belajar bahasa Inggris di sekolah?

They read novel at home

Mereka membaca novel di rumah

Do they reaf novel at home?

Yes, they do

No. They don't

Apakah mereka membaca novel di rumah? 
Setelah menguasai pertanyaan interrogative, langkah selanjutnya adalah menguasai pertanyaan $W-H$ Question, untuk menguasai langkah ini kohai harus menguasai interrogative dengan baik. Rumus untuk membuat pertanyaan itu sebagai berikut:

$W-H$ question + do/does + subject + verb $1+O$ (jika dalam Simple Present).

Atau

$W-H$ question + did + subject + verb $1+O$ (jika dalam Past Tense).

Misalnya:

(+) Tommy lives in Batam

Tommy tinggal di batam

(w-h question) where does Tommy live?

Di manakah Tommy Tinggal?

My husband's nama is Hendri

Nama suami saya adalah Hendri

What is your husband's name?

Untuk melatih conversation alangkah baiknya kohai mulai percakapan ringan, percakapan sehari-hari seperti:

Good morning, how are you?

Morning, I am fine, and you?

Where do you live?

I live at jalan Gajah Mada, Perumahan Puri Malaka N0. 10

What is your job?

I am a student

Untuk latihan bahasa Inggris ini tidak hanya di baca, di samping membaca kohai-kohai dan pembaca juga harus mengaplikasikannya setiap hari. Dengan latihan setiap hari, hasil yang memuaskan akan mudah didapatkan.

\section{PENUTUP}

English conversation adalah bagian dari komunikasi yang menggunakan bahasa asing sebagai bahasa utama. Dalam setiap komunikasi, kohai wajib menguasai vocabulary, pronounciation, structure, dan mengeasai bentuk-bentuk pertanyaan. Di sisi lain kohai harus mengaplikasikan conversation itu setiap hari, sekurang-kurangnya satu jam dalam sehari. Latihan itu dapat berupa cara melafalkan kata-kata yang akan digunakan, sehingga dapat membentuk satu kalimat serta membuat pertanyaan-pertanyaan yang akan diperlukan dalam percakapan itu.

Penulis melakukan pengabdian ini bertujuan untuk meningkatkan kualitas kohai-kohai dalam berbicara dengan menggunakan bahasa asing. Khususnya dalam menggunakan bahasa Inggris pada percakapan sehari-hari. Di samping itu, penulis barharap pada para pengabdi lainnya untuk melanjutkan pengabdian ini. 


\section{DAFTAR PUSTAKA}

Bonvillain. (1977). Language, Culture and Communication: The Meaning of Messages. New Jersey: Prentice-Hall, Inc.

Field, J. ( 2003.). Psycholinguistics A Resource Book For Students. USA and Canada : Routledge.

Johan, Mhd., Evyanto, W. (2021). Cara menguasai English vocabulary pada kohai karate Tanjung Pinang. 2(2), 119-124. Jurnal Puan

Johan, M., \& Wijayanti, I. (2020). Pengaruh fonem terhadap morfem pada ujaran anak balita: Suatu kajian neuro-morphology. Deiksis, 12(2), 192-203. https://doi.org/10.30998/deiksis.v12i02.4622

McCarthy., C. A. (2002). Carstairs Andrew -McCaAn Introduction to English Morphology: words and their structure. . Edinburgh: EdinburghUniversity Press.

Nadra. (2010). Bahasa dan Teknik Penulisan Karya IImiah \&Surat Resmi. Padang: Andalas university Press.

Semi, M. A. (2008). Stilistika Bahasa. Padang: University Negeri Padang Press. 
